DOI: 10.20472/IAC.2019.045.005

\title{
CHARU BHURAT
}

SVKM's NMIMS Anil Surendra Modi School of Commerce, India

\section{BRICS NATIONS AND FINANCIAL INCLUSION: A COMPARATIVE STUDY OF THE BRICS NATIONS USING VARIOUS FINANICAL INCLUSION INDICATORS}

\begin{abstract}
:
Financial inclusion means providing access to financial services at affordable cost to all individuals and businesses especially to the vulnerable and weaker income groups. This paper aims to examine the concept of financial inclusion and its relevance with respect to the world's emerging economies Brazil, Russian Federation, India, China and South Africa (BRICS). The BRICS nations have been the growth drivers of the world economy and higher financial inclusion means a better level of socio-economic development. Various financial inclusion indicators from The Global Partnership for Financial Inclusion (GPFI) have been used to compare data of these countries. With the help of this paper, an attempt has been made to analyse the state of financial inclusion and digital financial services amongst BRICS nations. Also, the BRICS nations have been compared in terms of income as well as gender disparity for various financial inclusion indicators.
\end{abstract}

\section{Keywords:}

BRICS, Financial inclusion, digital transactions, banking

JEL Classification: E02, E44, F33 


\section{Introduction}

Brazil, Russia, India, China and South Africa (BRICS) are the world's emerging economies and centers of political power. The term was first coined in 2001 to highlight the important role of these emerging economies and only included Brazil, Russia, India and China (BRIC). It was pointed out that high rates of growth, demographic development and economic potential and were going to put BRIC nations at the forefront and it was argued that their increased significance should also reflect in their incorporation to the G7 group. These four nations themselves started to meet as a group in 2006 and in 2010 South Africa also became a part of the group, which was then called as BRICS. Due to their geographic and demographic dimensions, the BRICS nations are strongly influencing global development, especially in Low Income Countries (LIC). They are strong economies promoting international trade and commerce and providing stability to the world economy in the times of financial crisis.

Financial inclusion means provision of financial services at affordable and low cost to all individuals and businesses especially to the vulnerable and weaker income groups. It aims at providing a wide array of financial services ranging from banking to insurance and equities at a reasonable cost. It widens the overall resource base of the banking and financial system by inculcating a culture of savings among large section of urban and rural population and plays its own role in the process of economic development. Further, by including low income groups within the periphery of formal banking sector; financial inclusion helps in protecting their wealth during difficult circumstances. Financial inclusion also reduces the exploitation of low income groups by unorganized money lenders.

Financial access helps in facilitating day to day living and helps households and firms plan for different things ranging from long-term goals to unexpected contingencies. As accountholders, people are more likely to use certain other financial services, such as insurance and credit services, to start and expand businesses, invest in education or healthcare, manage risk which can improve the standard of living of the people.

A lot of measures have been taken to increase financial inclusion especially of the weaker sections and 1.2 billion adults across the globe have access to an account since 2011. Today, $69 \%$ of adults have an account.

Having an access to account to account usage is the next logical step for nations where $80 \%$ or more of the population have accounts (China, Kenya, India, Thailand). These nations have relied on financial reforms, innovation by private sector, and a push to open low-cost accounts, including mobile and digital payments.

But if we still look at the bigger picture, close to one-third of adults around 1.7 billion are still unbanked. About half of unbanked people include women from poor households in rural areas or out of the workforce. 
The gender gap in terms of access and usage of accounts is a problem in developing countries, becoming a hindrance for women from being able to effectively control their financial lives. Countries which have high mobile money account ownership have less gender inequality.

Since 2010, more than 55 nations have formulated goals towards achieving a higher financial inclusion, and more than 60 have either started or are developing a strategy towards achieving the same. When countries take a strategic approach and develop national financial inclusion strategies, they increase the pace and impact of reforms.

Countries that have achieved the most progress toward financial inclusion have:

- Policies delivered at scale, such as universal digital ID - India and Aadhaar / Jan Dhan Yojana (JDY) accounts covered more than 1.2 billion residents.

- Leveraging government payments.

- Allowed digitization of financial services.

-Welcomed new businesses, such as leveraging e-commerce for financial inclusion.

The G20 is an international forum for economic development that promotes open and constructive discussion between developed and emerging-market economies on important issues related to global economic stability. The member countries of G20 are Argentina, Brazil, Australia, China, Canada, France, Germany, India, Indonesia, Italy, Japan, Korea, Russia, Mexico, Saudi Arabia, South Africa, Turkey, the United Kingdom, the United States and the European Union. They recognize the key role of financial inclusion in the realisation that it is a significant agent in the fight against poverty and inclusive development is leading to a focus on financial inclusion policies and initiatives.

The Global Partnership for Financial Inclusion (GPFI) is an inclusive platform for all G20 countries to work systematically towards financial inclusion. They developed a comprehensive set of financial inclusion indicators, with the aim of realizing the understanding of the financial inclusion landscape.

The focus of the present study is on following objectives: Firstly, to understand the extent of bank accounts created and loans availed from such accounts in BRICS nations. Secondly, to compare the financial inclusion indicators based on GPFI in these countries. Finally, to understand the reasons which come in the way of expansion of banking facilities in BRICS nations. The study is organized in the following sections. The background of BRICS countries and concept and progress of financial inclusion in these countries is briefly presented in Section I. In Section II, a brief review of literature is presented. In Section III, research objectives and methodology adopted for the study is 
described. In Section IV, analysis and interpretation of data based on secondary research is presented. Finally, Section V presents conclusions and policy recommendations.

\section{Literature Review}

Raccanello \& Sundaram (2016) in their paper write about the status of financial education and financial inclusion in BRICS countries where inequality and poverty is rampant. They reviewed how BRICS countries are managing such issues. Data from the Standard \& Poor's Ratings Services Global Fin Lit Survey 2014 was used to analyze financial literacy and the Global Financial Inclusion Database 2014 and the Financial Access Survey 2015 to study and examine the financial inclusion indicators. It was difficult to assess whether people would be capable to use financial instruments and reap the benefits of the financial inclusion. Thus, the study doesn't answer the questions on universal financial access.

Singh and Naik (2017) examine the impact of measures by the RBI and NABARD in opening of accounts, availing of loans from formal institutions, ease of transactions, and factors hindering financial inclusion in rural areas in India.

Levine (1997) empirically tested and found out that nations with bigger banks and more active stock markets grew faster over previous decades even after regulating many other factors underlying economic growth. Financial inclusion can also play an important major role in reducing poverty. A well developed financial system which gives access to everyone reduces information and transaction costs, influences saving rates, technological innovation, investment decisions and long-run growth rates.

Binswanger and Khandker (1995) and Pande and Burgess (2003) found out that Indian rural banks expansion program phenomenally lowered rural poverty, and increased employment which is unrelated to agriculture. A key goal in macro economics is to find out ways to get people out of poverty. Access to finance has been seen as a very significant factor in enabling people to transform their production and employment activities and to exit poverty (Aghion and Bolton 1997, Banerjee 2001, Banerjee and Newman 1993, Pande and Burgess 2003, Yunus 1999). In recent years, financial inclusion has assumed public policy relevance. Many countries like India,United Kingdom and International organizations like the United Nations, World Bank have set up committees to design goals and understand financial inclusion and to improve its scope. These studies throw light on various aspects of financial inclusion. However, the measurement aspect of financial inclusion has not been covered extensively by these reports. For India, being a very well diversified economy and society, it is of prime importance to give a lot of attention to measurement of financial inclusion. 
Sarma (2008) developed an Index for financial inclusion using different banking variables like number of bank branches, accounts and total credit and deposit as proportion of GDP for 55 countries. Honohan (2007) studied a part of the adult population using the information on number of banking and MFI accounts for more than 160 countries, and then correlated with inequality (Gini Coefficient) and poverty. World Bank (2008) provides a composite measure of access to financial services, that is, the percentage of adult population that has an account with a financial intermediary for 51 countries. While World Bank (2009) in Banking the Poor studied and examined the association between access to banking services, as measured by the number of bank accounts per thousand adults in each country, and many other factors like transactions offered at banks, or required by banks, that may affect banking access for 45 countries. Mehrotra et al. (2009) also designed an index for financial inclusion using similar financial inclusion indicators like number of rural offices, number of rural deposit accounts, volume of rural deposit and credit from banking data for sixteen major states of India. Beck et al. (2009) analyzed the availability of copious amount of data on many aspects of the financial system, but systematic indicators of financial sector inclusiveness are lacking.

Sadhan Kumar Chattopadhyay in a working paper for RBI on Financial Inclusion in India: A case-study of West Bengal (2011), have observed the extent of financial inclusion in West Bengal. According to the study there has been an improvement in outreach activity in the banking sector, but the achievement is not significant.

Bagli and Dutta (2012) in their study seek to examine the achievement of the Indian states regarding the financial inclusion. They used the methodology of Rotated Principal Component Analysis. For this analysis ten indicators of financial Inclusion have been considered. This study has used the data published by the Reserve Bank of India (RBI) and the Government of India. Ranks of the states in accordance with the Composite score show that although the state of Goa is the best, most of the states in southern region have performed better in terms of financial inclusion. However, the levels of financial inclusion of the states in India have a low mean and high disparity. This study has revealed a strong positive association between the human development and the financial inclusion of the states in India.

\section{Methodology and data}

The study is exploratory and descriptive in nature. Secondary data has been used for the study. The G20 Financial Inclusion indicators have been used for comparison of data across BRICS nations. Financial inclusion is measured in three dimensions: (i) access to financial services; (ii) usage of financial services; and (iii) the quality of the products and the service delivery. The data sources include the World Bank Global Findex database, IMF Financial Access Survey, OECD National Financial Literacy and Financial Inclusion 
Surveys. Different studies have considered different sets of the indicators of financial inclusion in accordance with their objectives.

A cross sectional study of the five BRICS nations has been done for the year 2017. For a few indicators time series study has been done from the year 2011to 2017. BRICS nations have been studied on the basis of various G20 financial indicators as mentioned below:

- Access to a mobile phone

- Access to Account

- Cashless transactions

- Adults using digital payments

- Payment using a mobile phone (from an account)

- Payments using the internet

- Payment using a bank card

\section{Analysis of Data and Findings}

The data has been based on Secondary findings. All data has been collected from Global Partnership for Financial Inclusion (GPFI) and World Bank. The data has been studied on the basis of both Time-series and Cross sectional analysis. The results have been shown as follows:

- Access to a mobile phone (\% age $15+$ )

It denotes the percentage of respondents, age $15+$, who report having access to a mobile phone.

Figure 1 represents a comparison between the 5 BRICS nations for the year 2017. It can be seen from the figure that Russia has the highest reported access to a mobile phone at $96.58 \%$ with China not far behind at $93.45 \%$. The lowest mobile phone access is for India at $68.53 \%$. 
Figure 1: Access to a mobile phone (\% age $15+)$

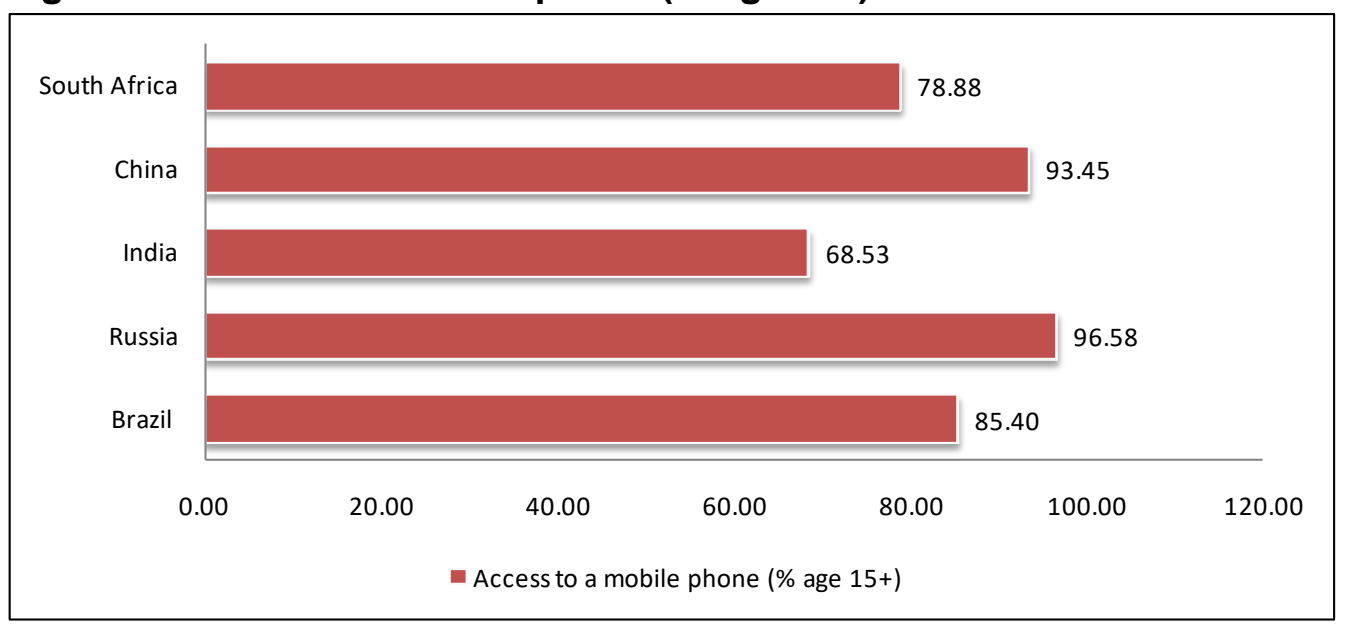

Source: World Bank Global Findex database

- Access to a mobile phone: male-female (\% age $15+)$

It denotes the percentage of male-female respondents, age 15+, who report having access to a mobile phone. It can be observed from Figure 2 that the highest access to a mobile phone for females is in Russia at $96.84 \%$ whereas for males is also in Russia at $96.26 \%$. There is very little disparity between males and females in Russia. The other nations also show very little disparity in terms of access to a mobile phone except India where a glaring disparity can be seen. Only $58.86 \%$ of women and $77.89 \%$ men have access to a mobile phone in India. The main reason for this disparity in India is lack of access to a mobile phone in rural areas and illiteracy.

Figure 2: Access to a mobile phone: male-female (\% age $15+)$

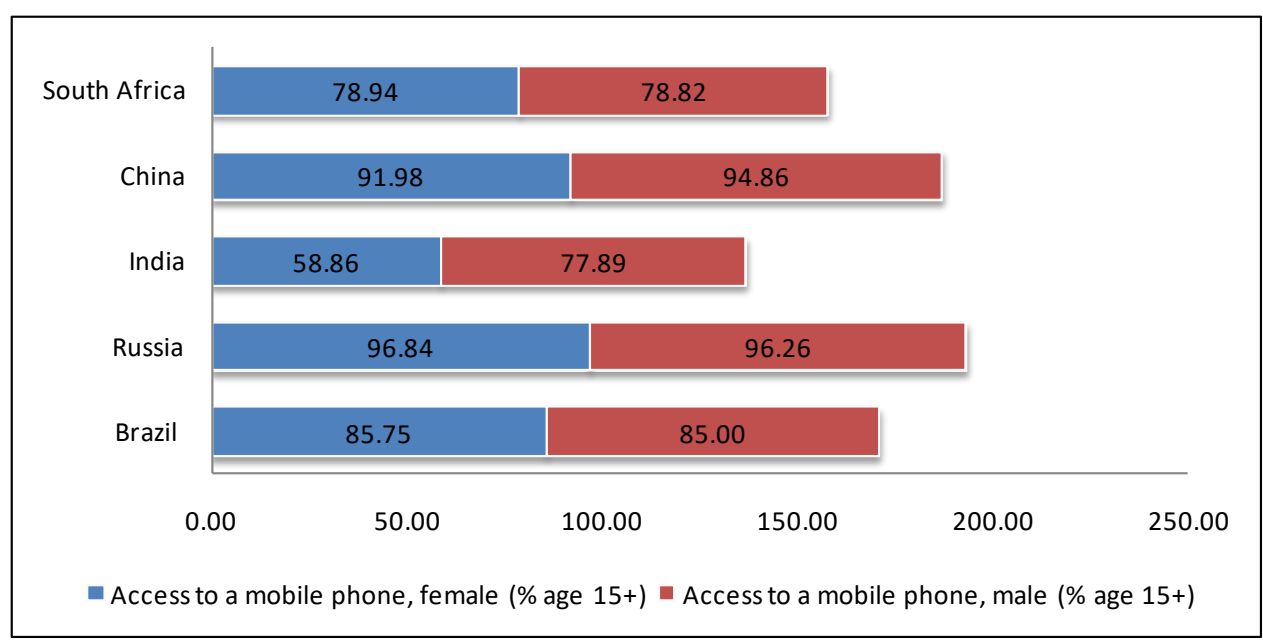

Source: World Bank Global Findex database

- Access to a mobile phone: Income disparity 
It denotes the percentage of respondents in the poorest $40 \%$ and richest $60 \%$ of households, age 15+, who report having access to a mobile phone. It can be observed that Russia has the highest reported access to a mobile phone which is $96.44 \%$ for poorest $40 \%$ and $96.67 \%$ for the richest $60 \%$. Brazil and India data show a lot of disparity for the poorest $40 \%$ and richest $60 \%$.

\section{Figure 3: Access to a mobile phone: Income disparity}

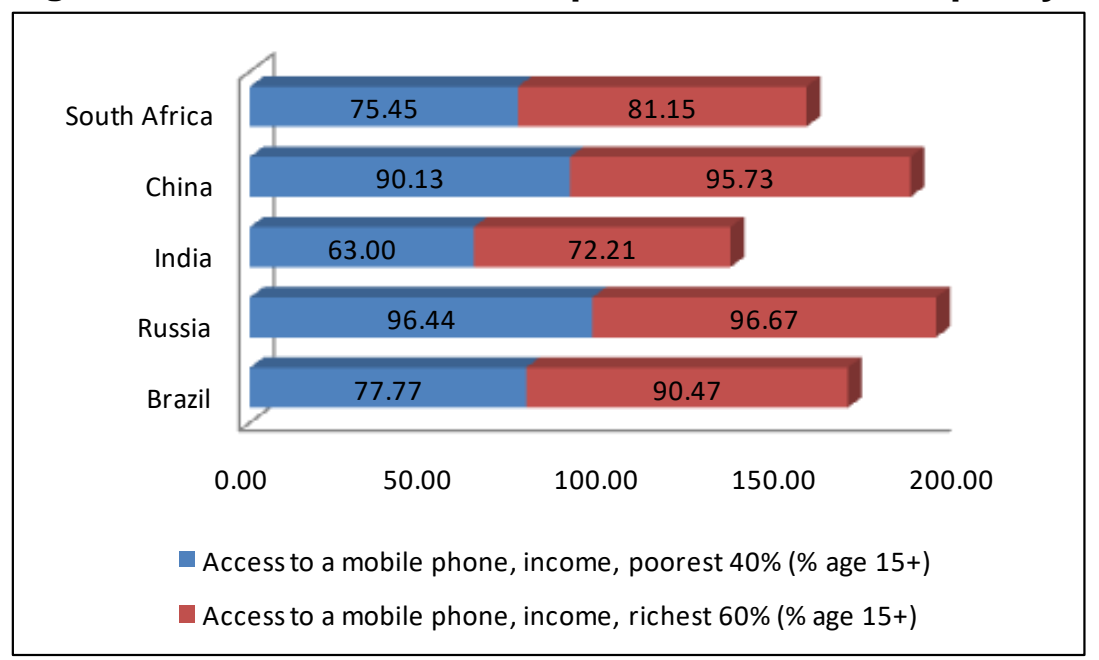

Source: World Bank Global Findex database

- Account and Active account (\% age 15+)

It denotes the percentage of respondents, age 15+, who report having an account (by themselves or together with someone else) at a bank or another type of financial institution or personally using a mobile money service in the past 12 months. It can be observed that China has the highest number of reported accounts at $80.23 \%$ followed by India at $79.88 \%$. The least number of accounts are in the South African economy.

Figure 4: Account and Active account (\% age 15+)

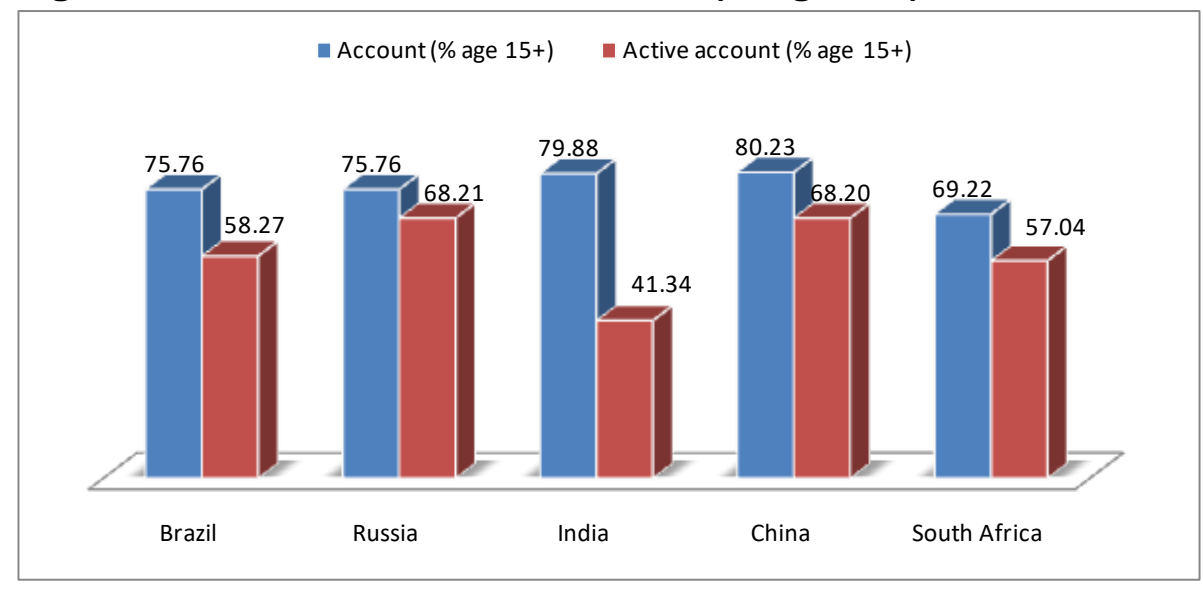

Source: World Bank Global Findex database 
It can also be observed from Table 1 that the compounded annual growth rate (CAGR) is the highest for India between the year 2011 to 2017. It means that the number of accounts grew by $14.6 \%$ for India which is phenomenally higher than the other BRICS nations.

Table 1: Compounded Annual Growth rate for Account (\%age 15+) for BRICS

\begin{tabular}{|l|r|r|r|}
\hline Account (\% age 15+) & 2011 & 2017 & CAGR \\
\hline Brazil & 55.86 & 70.04 & $3.8 \%$ \\
\hline Russia & 48.18 & 75.76 & $7.8 \%$ \\
\hline India & 35.23 & 79.88 & $14.6 \%$ \\
\hline China & 63.82 & 80.23 & $3.9 \%$ \\
\hline South Africa & 53.65 & 69.22 & $4.3 \%$ \\
\hline
\end{tabular}

Source: World Bank Global Findex database

- Account, male-female (\% age 15+)

It denotes the percentage of male and female respondents, age 15+, who report having an account (by themselves or together with someone else) at a bank or another type of financial institution or personally using a mobile money service in the past 12 months.

Figure 5: Account, male-female (\% age 15+)

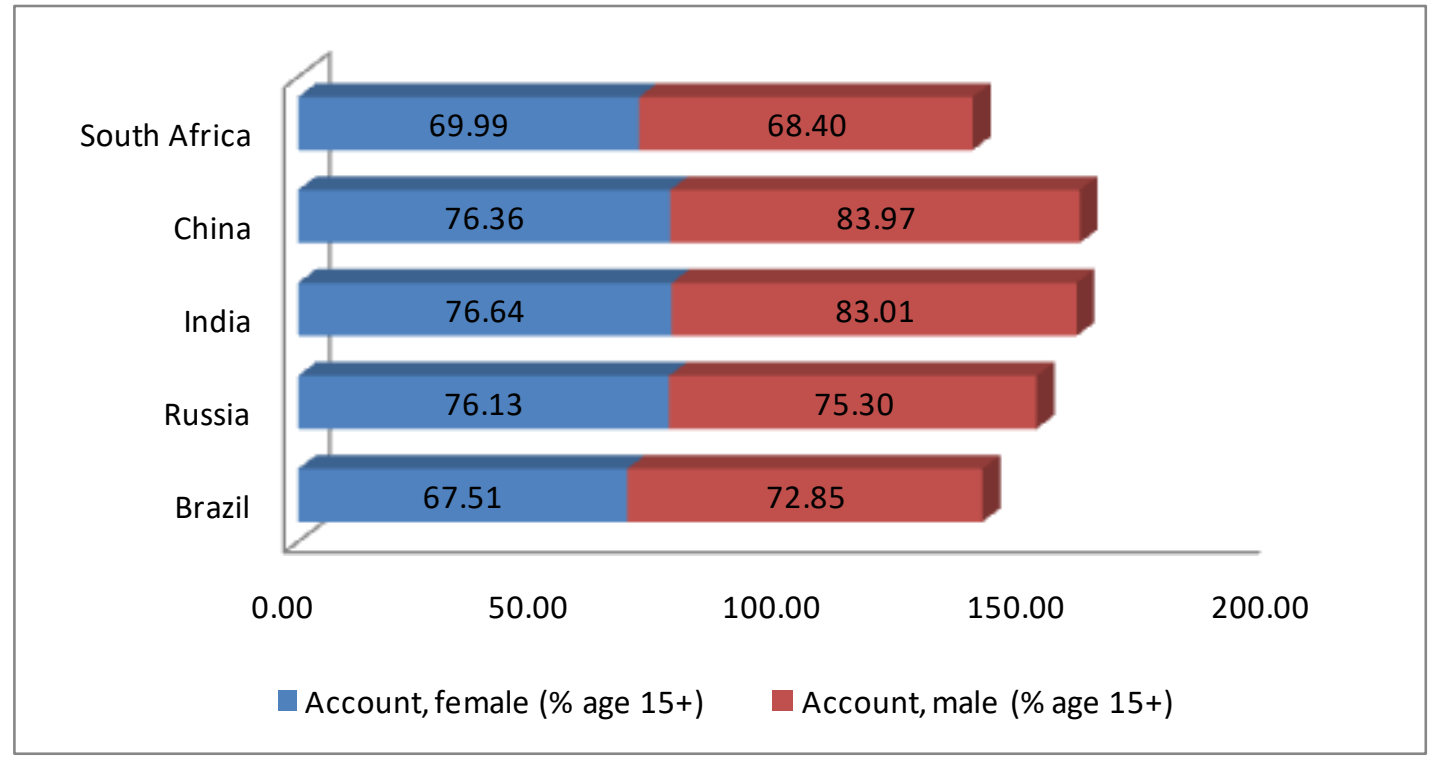

Source: World Bank Global Findex database

It can be observed from the figure 5 that India and China are almost at par when it comes to number of accounts opened by men and women. The least number of accounts for males and females have been recorded by South Africa.

-Account: Income Disparity 
It denotes the percentage of respondents in the poorest $40 \%$ and richest $60 \%$ of households, age 15+, who report having an account (by themselves or together with someone else) at a bank or another type of financial institution or personally using a mobile money service in the past 12 months.

Figure 6: Account: Income Disparity

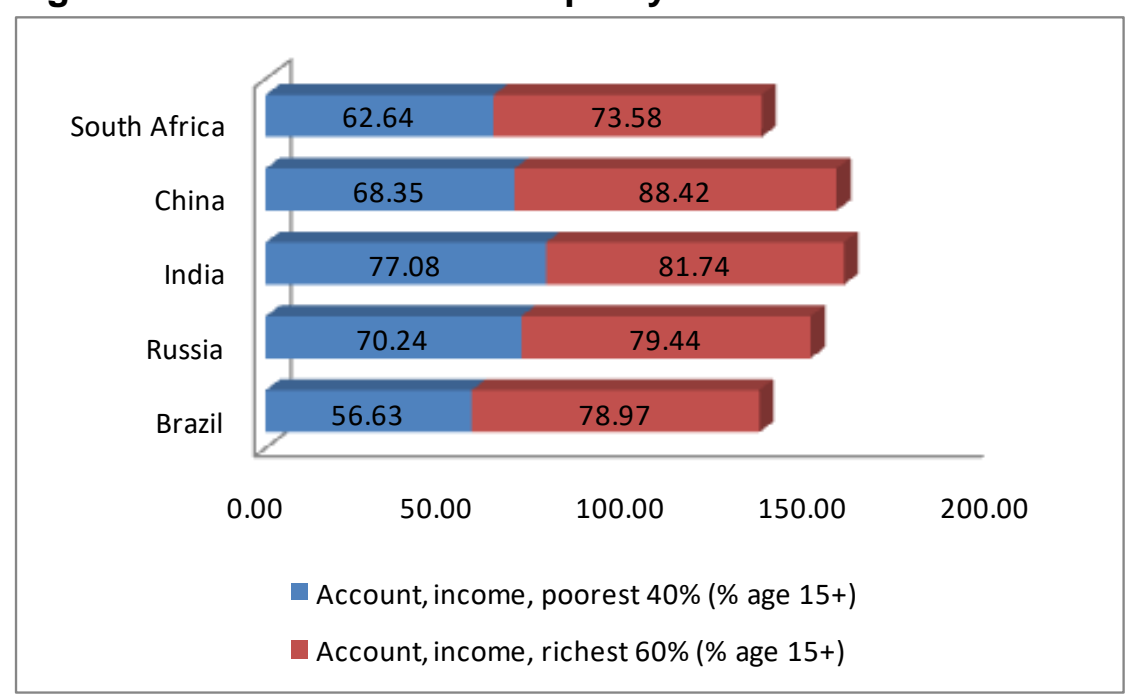

Source: World Bank Global Findex database

-ATMs and Branches per 100,000 adults

It denotes the total number of ATMs for every 100,000 adults in the reporting country. It is calculated as (number of ATMs) ${ }^{*} 100,000 /$ adult population in the reporting country. Automated teller machines are computerized telecommunications devices that provide clients of a financial institution with access to financial transactions in a public place.

Branches per 100,000 adults: Denotes the number of branches of commercial banks for every 100,000 adults in the reporting country. Calculated as (number of institutions + number of branches) ${ }^{*} 100,000 /$ adult population in the reporting country.

It can be observed that for India, the number of branches and ATMs per 100,000 adults is extremely low as compared to the other BRICS nations. Russia has the highest number of ATMs and branches per 100,00 adults. Data for China was not available for comparison. 
Figure 7: ATMs and Branches per 100,000 adults

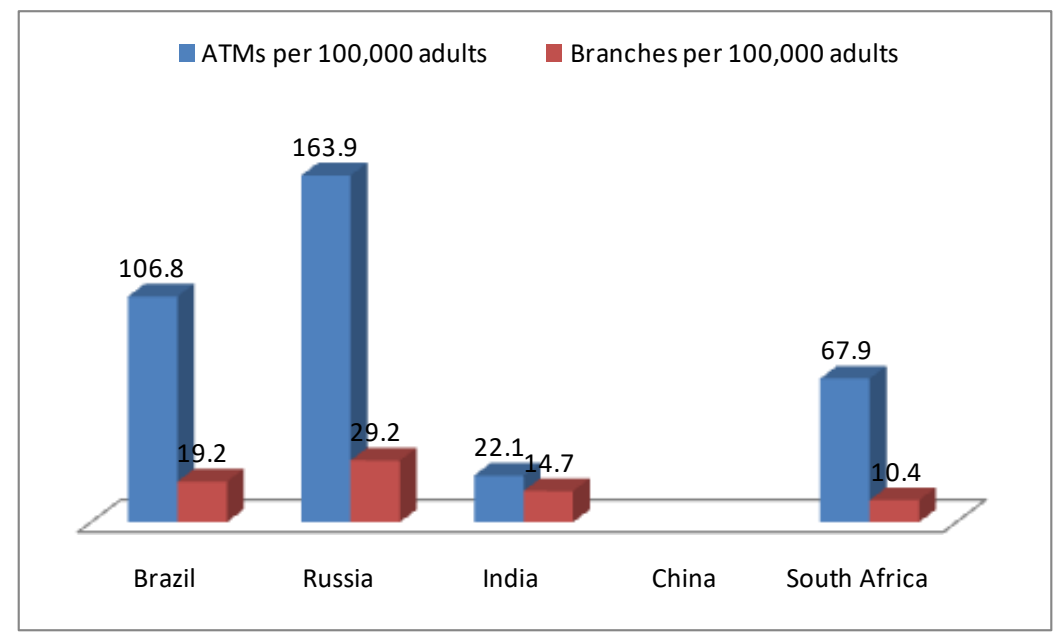

Source: World Bank Global Findex database

- Made or received digital payments in the past year (\% age 15+)

It denotes the percentage of respondents, age 15+, who report using mobile money, a debit or credit card, or a mobile phone to receive a payment through an account in the past 12 months. It also includes respondents who report receiving remittances, receiving payments for agricultural products, receiving government transfers, receiving wages, or receiving a public sector pension directly into a financial institution account or through a mobile money account in the past 12 months. It can be observed that Russia has the highest percentage of people who have digital payments in the past year. India has the lowest percentage of people (28.69\%) who have done digital payments. The reason behind this could be illiteracy, usage of cash as a safer means of transacting and nonavailability of internet services. If we see the data on access to internet for ages $15+$ it can be seen that only $14.1 \%$ people in India have access to internet. This makes it very difficult to execute digital transactions. 
Figure 8: Made or received digital payments in the past year (\% age 15+)

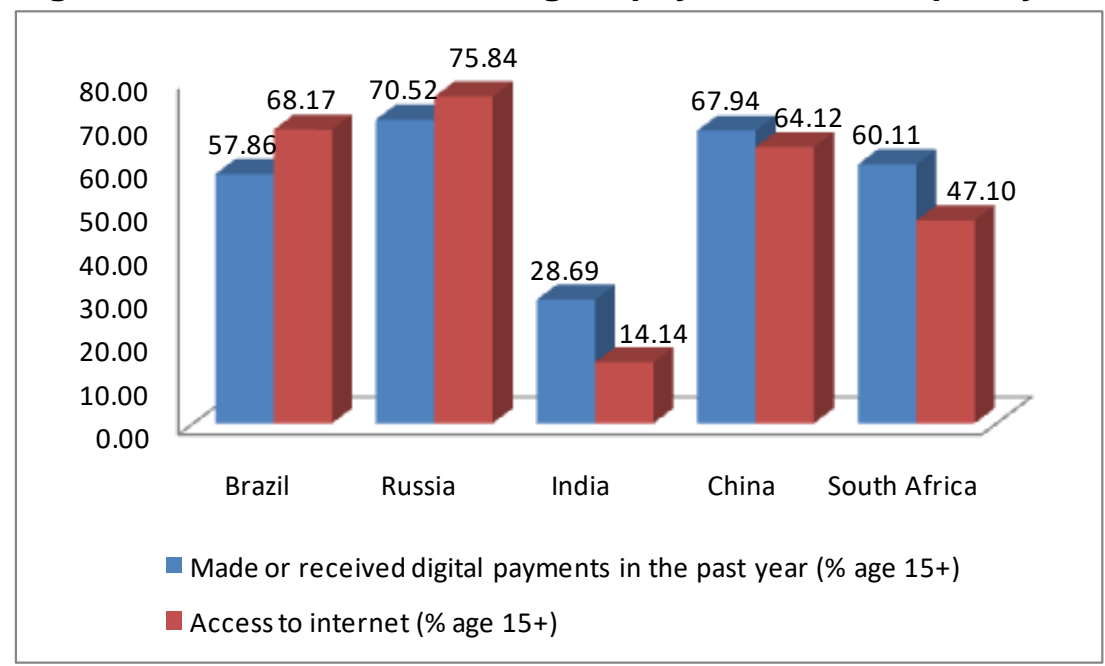

Source: World Bank Global Findex database

-Borrowed from a financial institution or used a credit card (\% age 15+)

Borrowed from a financial institution or used a credit card (\% age 15+): Denotes the percentage of respondents, age 15+, who report borrowing any money from a bank or another type of financial institution or using a credit card in the past 12 months. It can be observed that India has the least amount of borrowings using a credit card (8.15\%). Whereas Brazil has the highest amount of borrowings using a credit card (26.29\%).

\section{Figure 9: Borrowed from a financial institution or used a credit card (\% age 15+)}

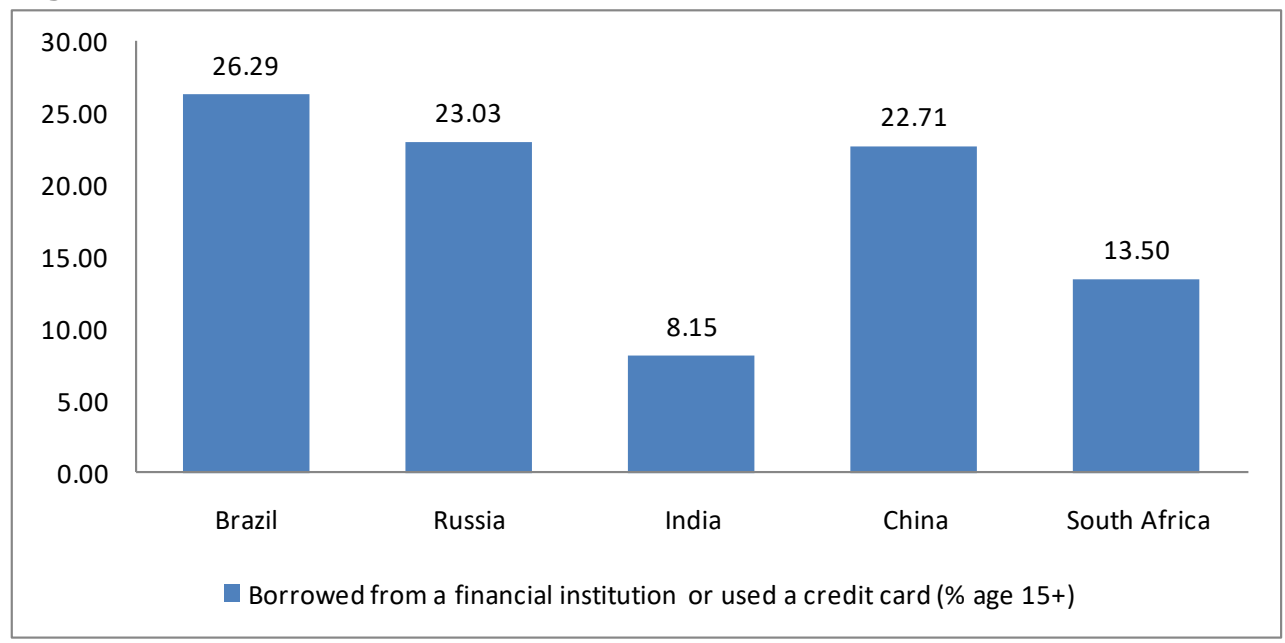

Source: World Bank Global Findex database

- Used a debit or credit card to make a purchase in the past year (\% age 15+)

It denotes the percentage of respondents, age 15+, who report using a debit or credit card to make a purchase in the past 12 months. It can be observed that India has the least amount of debit or credit card purchases in the past year (12.33\%) as compared to Russia which has the highest percentage $(45.64 \%)$ of people who have done debit or 
credit card purchases. The number of active accounts ages $15+$ is very low in India $(41.33 \%)$ as compared to Russia where active accounts are $68.21 \%$.

Figure 10: Used a debit or credit card to make a purchase in the past year (\% age 15+)

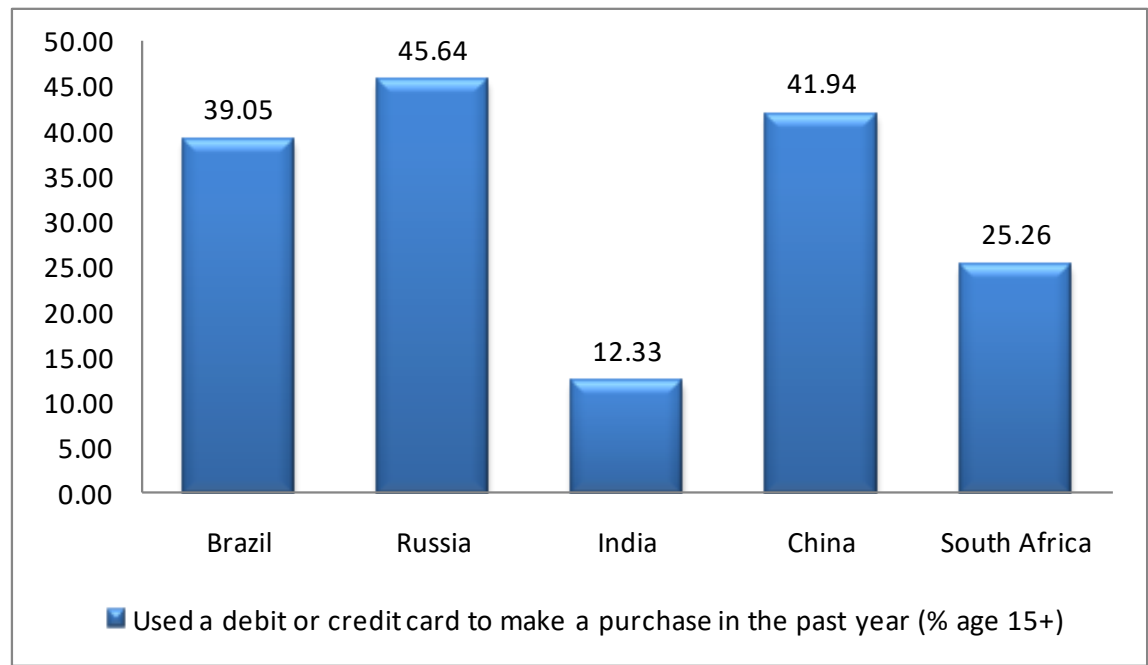

Source: World Bank Global Findex database

- Access to mobile phone, Access to internet and payments made by using mobile phone or internet $(\% 15+)$

The figure has been made using three variables access to mobile phones, access to internet and payments made using mobile phone or internet (\% age 15+). It can be observed from the figure that the eventhough the highest access to mobile phone and internet is in Russia but in terms of payment made using mobile phone or internet, it is China which ranks the highest. Overall, 39.81\% people over 15 years made payments using mobile phone or internet in China. India has only $5.63 \%$ of people who made payment using mobile phone or internet despite having a high access to mobile phone. The main drawback for India is the low internet access. Only $14.14 \%$ of people have access to internet which makes digital transactions very difficult. 
Figure 11: Access to mobile phone, Access to internet and payments made by using mobile phone or internet $(\% 15+)$

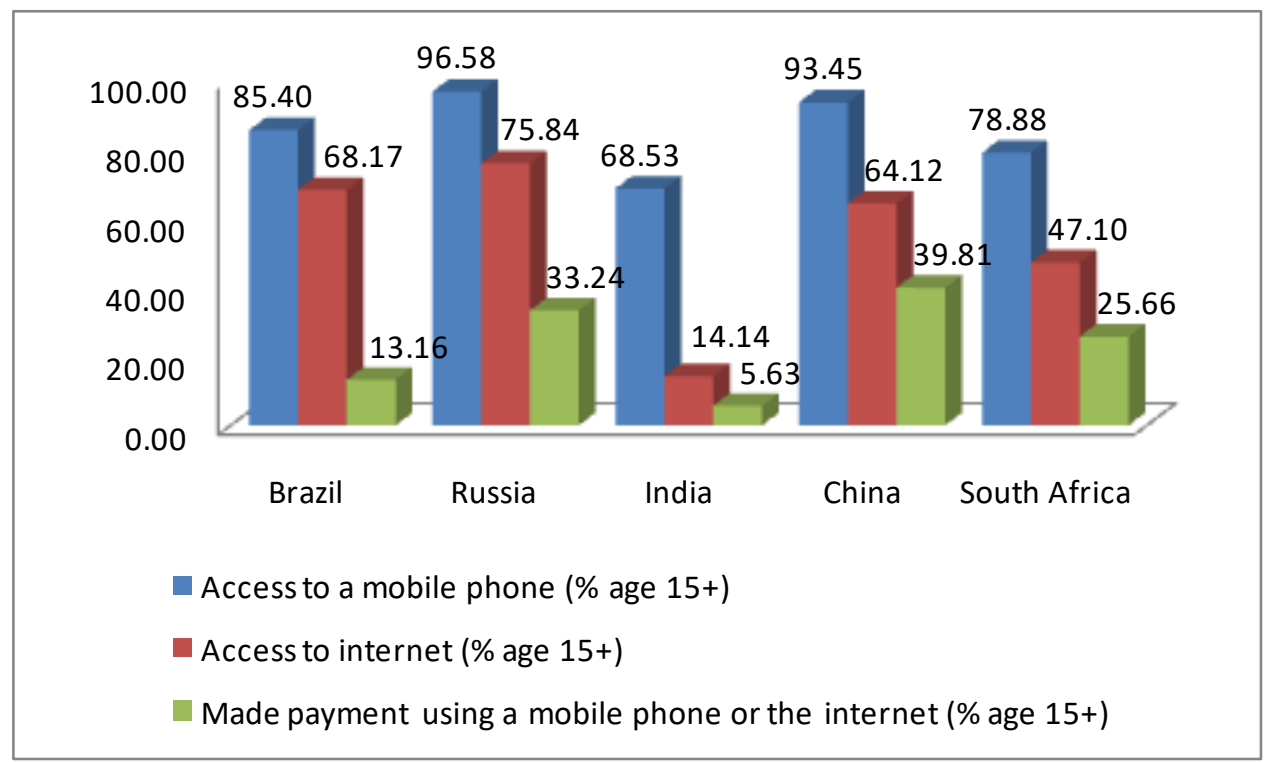

Source: World Bank Global Findex database

- Saved at a financial institution (\% age 15+)

It denotes the percentage of respondents, age 15+, who report saving or setting aside any money by using an account at a bank or another type of financial institution in the past 12 months.

\section{Table 2: Saved at a financial institution (\% age 15+)}

\begin{tabular}{|l|r|r|r|}
\hline Saved at a financial institution (\% age 15+) & 2011 & 2017 & CAGR \\
\hline Brazil & 10.29 & 14.50 & $5.9 \%$ \\
\hline Russia & 10.88 & 13.52 & $3.7 \%$ \\
\hline India & 11.60 & 19.60 & $9.1 \%$ \\
\hline China & 32.09 & 34.78 & $1.4 \%$ \\
\hline South Africa & 22.08 & 22.09 & $0.01 \%$ \\
\hline
\end{tabular}

Source: World Bank Global Findex database

It can observed from Table no. 2 that between 2011 to 2017 the compounded annual growth rate (CAGR) for savings at a financial institution were the highest for India at $9.1 \%$. It means that India has made remarkable progress in getting a bigger portion of people under the financial system which has brought about a growth in savings for India between 2011 to 2017. 


\section{Correlation Analysis}

The given below data variables have been analysed using MS- Excel Data Analysis Toolpak.

1. Correlation between Access to internet and Making or receiving digital payments (\%age 15+)

Table 3: Access to internet and Making or receiving digital payments (\%age 15+) for year 2017

\begin{tabular}{|c|c|c|}
\hline Year 2017 & Access to internet (\% age $15+$ ) & $\begin{array}{l}\text { Made or received digital payments in the past year } \\
(\% \text { age } 15+)\end{array}$ \\
\hline Brazil & 68.16731 & 57.86 \\
\hline Russia & 75.83771 & 70.52 \\
\hline India & 14.13886 & 28.69 \\
\hline China & 64.12061 & 67.94 \\
\hline South Africa & 47.10382 & 60.11 \\
\hline
\end{tabular}

Table 4: Correlation Analysis

\begin{tabular}{|c|c|c|c|}
\hline & Column 1 & & $\begin{array}{c}\text { Column } \\
2 \\
\end{array}$ \\
\hline Column 1 & & 1 & \\
\hline Column 2 & & 0.929489145 & 1 \\
\hline
\end{tabular}

Table 3 shows the data variables for the year 2017 for the five BRICS nations. Table 4 shows the correlation analysis between the two variables Access to internet and making or receiving digital payments (\%age 15+). It can be observed that the correlation coefficient is +0.9294 which means there is a strong positive correlation between the 2 variables. Access to internet is strongly correlated to making or receiving digital payments. Higher the access to internet more will be the digital transactions.

2. Correlation between Using a debit or credit card to make a purchase in the past year and active accounts(\%age 15+) 
Table 5: Using a debit or credit card to make a purchase in the past year and active accounts(\%age 15+)

\begin{tabular}{|l|l|l|}
\hline & Used a debit or credit card to make a purchase in & $\begin{array}{l}\text { Active } \\
\text { account } \\
\text { (\% age } \\
15+)\end{array}$ \\
\hline Brazil 2017 & $\begin{array}{l}\text { Use past year (\% age 15+) } \\
\text { the }\end{array}$ \\
\hline Russia & 39.05 & 58.26911 \\
\hline India & 45.64 & 68.21294 \\
\hline China & 12.33 & 41.33924 \\
\hline South Africa & 41.94 & 68.19982 \\
\hline
\end{tabular}

Source: World Bank Global Findex database

Table 6: Correlation Analysis

\begin{tabular}{lrrr}
\hline & Column & Column \\
& 1 & 2 \\
\hline Column 1 & 1 & \\
Column 2 & 0.943564 & 1 \\
\hline
\end{tabular}

Table 5 shows the data variables for the year 2017 for the five BRICS nations. Table 4 shows the correlation analysis between the two variables using a debit or credit card to make a purchase in the past year and active accounts (\%age 15+). It can be observed from Table 6 that the correlation coefficient is +0.9435 which means there is a strong positive correlation between the 2 variables. Using a debit or credit card to make a purchase is strongly related to percentage of active accounts. Higher the number of active accounts more is the usage of debit or credit card to make purchases.

\section{Conclusion and Recommendations}

Given the data analysis and research findings, some key conclusions can be made between the BRICS nations and financial inclusion in these countries. Firstly, there is a strong positive relationship between the percentage of people who have access to internet and the percentage of digital transactions done. The higher the access to internet, higher is the digitization. Secondly, the usage of debit/credit cards increases with the higher number of active accounts. Thirdly, Russia has the best financial inclusion indicators amongst all the BRICS countries on the basis of comparison of the various bar graphs. It can be attributed to a higher access to mobile phones, better internet access, better usage between males and females, higher number of active accounts. Fourthly, India is still lagging behind and has the least amount of financial inclusion amongst the 5 BRICs nations. It can be attributed to a very low internet access, lesser access to mobile 
phones especially amongst females, less number of active accounts. Fifthly, even though the least amount of financial inclusion is for India as an economy but comparing the compounded annual growth rate for the BRICS nations from the year 2011 to year 2017 we can see that India is the only nation which has made remarkable progress when it comes to access to accounts and people saving at a financial institution. Finally, the number of ATMs and branches per 1,00,000 adults is the least for India amongst the BRICS nations.

Financial inclusion can be improved amongst the BRICS nations by improving the access to mobile phones and bringing about better internet access. The number of ATMs and bank branches should be increased substantially so as to improve the level of financial inclusion. Financial inclusion can be improved by involving more women into the financial inclusion process especially with reference to India. The status of women with respect to financial inclusion is weak in India.

\section{References}

ATKINSON, A., \& MESSY, F. (2012). Measuring Financial Literacy: Results of the OECD / International Network on Financial Education (INFE) Pilot Study. OECD Working Papers on Finance, Insurance and Private Pensions, No. 15, OECD Publishing.

BATEMAN, M. (2010). Why microfinance doesn't work? The destructive rise of local neoliberalism. London: Zed Books.

COHEN, M., \& SEBSTAD, J. (2003). Financial Education for the Poor. (Working Paper no.1). Washington. D.C.: Microfinance Opportunities.

DEMIRGÜÇ-KUNT, A., KLAPPER, L. F., SINGER, D., \& VAN OUDHEUSDEN, P. (2015). The Global Findex Database 2014: measuring financial inclusion around the world. World Bank Policy Research Working Paper, (7255). Washington, D.C.: The World Bank.

DICHTER, T.W., \& HARPER, M. (EDS.). (2007). What's wrong with microfinance?. Rugby: Practical Action Publishing.

DRURY, L.L. III. (2009). Predatory Lending and Its Impact on Consumer Credit. Loyola Journal of Public Interest Law, 10(2), 137-148.

GLOBAL PARTNERSHIP FOR FINANCIAL INCLUSION [GPFI]. (2016). Global Partnership for Financial Inclusion (GPFI) China 2016 Priorities Paper. Retrieved on April 16th, 2019: http://www.gpfi.org/publications/global-partnership-financial-inclusion-gpfi-china-2016- prioritiespaper

HILGERT, M., HOGARTH, J.M., \& BEVERLY, S. (2003). Household Financial Management: The Connection Between Knowledge and Behavior. Federal Reserve Bulletin, 89, 309-322.

HILL, R.P., \& KOZUP, J.C. (2007). Consumer Experiences with Predatory Lending Practices. The Journal of Consumer Affairs, 41(1), 29-46. 
HOLZMANN, R., MULAJ, F., \& PEROTTI, V. (2013). Financial capability in low-and middle-income countries: measurement and evaluation. Financial Literacy and Education Russia Trust Fund. Washington, D.C.: The World Bank.

KUMAR, N. (2011). "Financial Inclusion and its Determinants: Evidence from State Level Empirical Analysis in India." 13th Annual Conference on Money and Finance in the Indian Economy, Indira Gandhi Institute of Development Research, Mumbai, February

LUSARDI, A., \& MITCHELL, O. (2007). Financial Literacy and Retirement Preparedness: Evidence and Implications for Financial Education. Business Economics, 42(1), 35-44.

LUSARDI, A. (2008). Financial Literacy: An Essential Tool for Informed Consumer Choice? Working Paper UCC08-11, Joint Center for Housing Studies, Harvard University.

MADER, P. (2016). Questioning Three Fundamental Assumptions in Financial Inclusion (Evidence Report No. 176). Brighton: Institute of Development Studies.

RACCANELLO \& SUNDARAM (2016). BRICS: Financial literacy and financial inclusion.

SINGH \& NAIK (2017) Financial Inclusion in India: A Case Study of Gubbi.

STANGO, V., \& ZINMAN, J. (2009). Exponential Growth Bias and Household Finance. Journal of Finance, 64(6), 2807-2849.

WORLD BANK. (2012). Financial inclusion strategies: reference framework. Washington, D.C.: The World Bank.

U.S. DEPARTMENT OF HOUSING AND URBAN DEVELOPMENT [US-HUD]. (2001). Curbing Predatory Home Mortgage Lending. Washington, D.C.: HUD-Treasury Task Force on Predatory Lending. 